\title{
TRADE OPENNESS AND UNEMPLOYMENT RATE IN NIGERIA
}

\author{
Philip Nwosa*, Sunday Keji, Samuel Adegboyo, Oluwadamilola Fasina \\ Department of Economics, Faculty of Social Sciences, Federal University Oye, Ekiti State, \\ Nlgeria \\ philip.nwosa@fuoye.edu.ng \\ sundav.keji@fuove.edu.ng \\ samuel.adegboyo@fuoye.edu.ng \\ oluwadamilola.fasina@fuoye.edu.ng
}

\begin{abstract}
This study examines the relationship between trade openness and unemployment rate in Nigeria from 1980 to 2018. The study utilized the auto-regressive distributed lag (ARDL) technique and the result of the study shows that trade openness had negative and significant impact on unemployment rate in Nigeria. The implication of this result is that trade openness provides employment opportunities, which reduces the unemployment rate in Nigeria. Thus, the study concludes that trade openness is a significant determinant of unemployment in Nigeria. The study recommends the need for conscious economic policies that would promote foreign private investment, capable of enhancing aggregate volume of investment in the country and contribute to employment generation in the Nigeria. Finally, government needs to explore new marketing areas for foreign investors which would also contribute to employment generation.
\end{abstract}

Keywords: Trade Openness, Unemployment, ARDL, Nigeria.

JEL Classification: F13, F16, J21.

\section{Introduction}

Globally, government has always introduced and implemented economic policies to achieve desired micro and macroeconomic objectives. Relatedly, the Nigerian government has over the years implemented various trade policies - export promotion strategy in 1981; trade liberalization policy in 1986; exchange rate liberalization in 1986; establishment of the Nigerian Export-Import Bank (NEXIM) in 1991; and entered several bilateral and multilateral trade agreements. These trade policies were expected to increase trade relations with the global community through ease movement of commodities across borders, importation of cutting-edge and modern technologies, accessibility of foreign currency, enhance inflow of foreign capital and knowledge spill-over, and facilitate the participation of foreign firms in domestic trade (UNCTAD, 2013). The inflow of these resources is expected to enhance the country's international competitiveness leading to higher production and generation of employment opportunities.

Furthermore, Khattry and Rao (2002) and Ebrill, Stotsky and Gropp (1999) argued that trade policy influences trade tax revenue. The removal of quotas and reduction of tariffs on imported goods lead to substantial increase in trade volumes and a decrease in the incentive to evade taxes; consequently resulting in higher trade revenue (Ifeakachukwu, 2018). The increase in trade revenue is expected to enhance the government finances in providing employment opportunities. In spite of the above narrative on the link between trade policy and unemployment, available data shows that increase in trade openness has not been

${ }^{*}$ Corresponding author: Philip, Nwosa. 
accompanied by reduction in unemployment rate (see appendix Figures 1 and 2) while empirical literatures on this issue have equally yielded mixed results. Kemal et al. (2003) observed that reduction in quantitative restriction on imports improve welfare of employees while Martes (2018) noted that trade openness had significant and negative impact on unemployment rate. Famode, Makalamba and Ngbolua (2020), and McMillian and Verduzco (2011) observed an insignificant relationship between trade policy and unemployment rate. With respect to Nigeria, little is known about the link between trade openness and unemployment rate, due to absence of indigenous studies on this issue. Most studies on trade openness have focused on its relationship with economic growth (Ude and Agodi, 2015; Arodoye and lyoha, 2014) while studies on unemployment have equally focused on its link with other macroeconomic variables such as economic growth, poverty and government spending (see Sodipe and Ogunrinola, 2011; Oloyede, 2014). In view of the paucity of knowledge on trade openness and unemployment, this study seeks to address the research question "what is the relationship between trade openness and unemployment rate Nigeria"? and the objective of this study is "to analyse the relationship between trade openness and unemployment rate in Nigeria". The outcome of this study would review the stand of the relationship between trade openness and unemployment rate which would provide the guide for policymakers on appropriate trade policy measures to be adopted in addressing the perennial problem of unemployment in Nigeria.

\section{Hypothesis Testing:}

Trade openness has an insignificant impact on unemployment rate in Nigeria.

\section{Literature Review}

Different theories have been developed with respect to international trade. The factor proportion model was developed by Heckscher and Ohlin (1991). The model introduced a second factor of production (capital) to the traditional model of David Ricardo. The model is a two-by-two variant that is there are two countries, two factors of production (capital and labour) and two goods. Also, the two countries have identical technology i.e. same production functions which are available for the two goods to be produce and the aggregate preference are the same for the two countries. The model assumes that the only differences that exist between the two countries are the variations in the relative endowments of factors of production. The Heckscher-Ohlin theory hypothesized that a capital-abundant country will export capital-intensive good while a labor-abundant country will export the labor-intensive good, thus, each country exports good which it produces relatively cheaper than the other country. In the Heckscher-Ohlin theory a country's advantage in production arises mainly from its relative factor abundance. Kreickemeier (2008) noted that the Heckscher-Ohlin structure predicts that trade liberalization would result in a reduction in unemployment only if the country in question is labor-abundant and would increase unemployment in a laborscarce economy. Thus, given that the Nigerian economy is labor-abundant, following the Kreickemeier (2008) proposition, it is expected that trade policy would influence employment through the provision of job opportunities.

Empirical evidence from existing literature explains the relationship between trade openness and unemployment rate. With respect to Nigeria, there is a paucity of knowledge as regard the relationship between trade openness and unemployment rate. However, there are nonindigenous empirical studies that have examined the relationship between trade openness and unemployment rate. Famode, Makalamba and Ngbolua (2020) examined the impact of trade openness on unemployment rate in Democratic Republic of the Congo (DRC) for the period 1991 to 2017. Employing the vector error correction estimation technique, the study observed that trade openness insignificantly influenced unemployment rate. Madanizadeh 
and Pilvar (2019) examined the relationship between trade openness and labour force participation rate for a panel of 93 countries over the period 1990 - 2012. Using fixed effect panel estimation technique, the study observed that trade openness significantly promote labour force participation rate. Mohler, Weder and Wyss (2018) examined the relationship between international trade and unemployment in Switzerland. The study covered the period $1991-2008$ with about 33,000 employees in the manufacturing sector. Using the panel regression technique, the study observed an insignificant relationship between international trade and unemployment. Martes (2018) analyzed the relationship between trade openness and unemployment rate for 28 OECD (Organization of Economic Corporation and Development) countries. The study covered the period 2000 - 2016 and the panel regression estimation technique was employed. The findings of the study showed that trade openness had significant and negative impact on unemployment rate both in the long run and short run. Awad-Warrad (2018) analyzed the impact of trade openness and economic growth on unemployment reduction in the Arab region. The study focused on 7 Arab countries (Algeria, Bahrain, Egypt, Jordan, Oman, Saudi Arabia and Tunisia) and covered the period 1990-2015. Using panel weighted least square estimation technique, the study observed that trade openness and economic growth significantly reduced unemployment in the Arab region.

Keawphun (2016) examined the impact of trade opening on unemployment using a linear regression model for 89 Countries for the period 1994 to 2005. Evidence from the study revealed that trade openness had negative relationship with unemployment. Anjum and Perviz (2016) examined the relationship between trade openness and unemployment for labour and capital abundant countries. The study focused on a panel of 75 labour abundant countries and 44 capital abundant countries for the period 1990 -2012. Using pooled mean group estimation technique, the study observed that in the long run, trade openness had a negative and significant impact on unemployment rate in labour abundant countries, while in capital abundant countries trade openness had positive and significant impact on unemployment rate. Carrere, Grujovic and Robert-Nicoud (2015) examined the link between trade openness and frictional unemployment in $31 \mathrm{OECD}$ Countries. The results of the study revealed that trade openness contributes significantly to reduction in unemployment in the sampled countries. Carrere, Fugazza, Olarreaga and Rodert-Nicoud (2014) examined the relationship between openness to trade and unemployment rate for a panel of 97 countries. The study covered the period 1995 to 2009 and the result of the study showed that the relationship between trade openness and unemployment rate depends on the covariance between sectoral labour market frictions and comparative advantages. A positive covariance implies that trade liberalization leads to increase in unemployment while a negative covariance signifies that trade liberalization leads to reduction in unemployment.

Ventura (2014) examined the impact of trade openness on female unemployment rate in developing countries over the period 1990 - 2012. The study covered 119 countries and utilized pooled ordinary least squares estimation technique. The result of the study showed that trade openness increased female unemployment rate. Gozgor (2013) examined the impact of trade openness on unemployment rate in G7 countries (Canada, France, Germany, Italy, Japan, the United Kingdom, and the United States). Using panel estimation technique, the study observed that trade openness and globalization had negative and significant impact on unemployment rate. Halit (2013) analyzed the relationship between trade liberalization and growth rate of sectoral employment in developed and developing countries. Using panel regression estimate, the study observed that trade liberalization had negative and significant impact on industrial sector employment in developed countries. Also, the study found that trade liberalization significantly enhanced employment in industry and services sectors in developing countries while trade barriers significantly reduced employment growth in services sector in the developed countries. Newfarmer and 
Sztajerowska (2012) examined the relationship between trade and employment. The study noted that trade played a vital role in job creation, increased wages in both rich and poor countries, and improve labour working conditions. Jaewon (2011) examined the link between international trade and unemployment rate for a panel of 20 OECD countries. The study covered the period 1961 to 2008 and the study concluded that international trade influenced aggregate unemployment as it interacts with rigid labour market institutions. Also, the study observed that with average degree of labour market rigidities, an increase in international trade had insignificant impact on unemployment rate.

Felbermayr, Prat and Schmerer (2011) analysed the relationship between unemployment and trade openness for a panel 20 OECD countries. The results of the study showed that increased trade openness is causally associated to a lower structural rate of unemployment through total factor productivity in the long-run. Costinot (2009) examined the determinants of trade protection in a small open economy with search frictions. The study observed that jobs generate rents, whose access depends on the level of trade protection. That is by increasing the domestic price of a good; a government may attract more firms in a particular industry and in turn increases the probability that workers will find jobs in this sector. Dutt, Mitra and Ranjan (2008) analyzed the relationship between international trade and unemployment for a panel of 92 countries over the period $1990-2000$. The study employed two alternative models - Ricardian and Heckscher-Ohlin, and the result of the study supports the Ricardian model, that international trade had negative impact on unemployment while the result did not find support for the Heckscher-Olin model that the relationship between international trade and unemployment changes from negative to positive, as countries move from labour-abundant to capital abundant.

The empirical studies reviewed above show clearly that there is an absence of indigenous studies explaining the link between trade policy and unemployment rate. Therefore, there is a need to examine the relationship between trade policy and unemployment rate with respect to Nigeria.

\section{Methodology of Research}

To examine the relationship between trade openness and unemployment in Nigeria, this study specifies the model below:

$U M P=f(T R D P)$

Introducing other control variables which are identified in the literature as important factors influencing unemployment rate (see Famode Makalamba and Ngbolua, 2020; AwadWarrad, 2018; Nwaka, Uma and Tuna, 2015), equation (1) becomes

$U M P_{t}=f\left(T R D P_{t}, G R T_{t}, G S I V_{t}, P C I_{t},\right)$

Linearing equation (2):

$U M P_{t}=\delta_{0}+\delta_{1} T R D P_{t}+\delta_{2} G R T_{t}+\delta_{3} G S I V_{t}+\delta_{4} P C I_{t}+\varepsilon_{t}$

From equation (3), UMP is the dependent variables while TRDP, GRT, GSIV and $P C I$ are the independent variables. UMP is unemployment rate, TRDP is trade openness measured by trade openness, GRT is the growth rate of real gross domestic product, GSIV is government size measured by the ratio of aggregate government expenditure to real gross domestic product, $P C /$ is per capita income, $\delta_{0}$ is constant and $\varepsilon_{t}$ is the stochastic error term. Theoretically, the expected relationship between trade openness and unemployment rate is indeterminate as argued in the literature while it is expected that an increase in economic 
growth (GRT), government size (GSIV) and per capita income (PCI) would reduce unemployment rate. This study employed both descriptive and appropriate econometric techniques based on the preliminary econometric tests such as the unit root and cointegration estimate. The data for this study is obtained from the Central Bank of Nigeria, Statistical Bulletin, 2018 edition.

\section{Data Analysis and Results}

\subsection{Descriptive Statistics and Covariance Estimate}

The descriptive statistics on Table 1 shows that the average values of the trade openness (TRDP), unemployment rate (UMP), growth rate of real gross domestic product (GRT), are 7.84, 12.47 and 3.24 respectively while the average values of government size (GSIV) and per capita income $(\mathrm{PCl})$ are 2.10 and 0.24 respectively. The standard deviation reveals that unemployment rate (UMP) and trade openness are the most unstable variables with 9.39 and 9.62 while per capita real income $(\mathrm{PCI})$ is the least volatile variable with $(0.07)$. It is worthy to note that the skewness statistics of growth rate of real gross domestic product (GRT) is negatively skewed while the other variables such as unemployment rate, trade openness, government size and per capital real income were positively skewed. The Kurtosis statistics reveal that rate of real gross domestic product (GRT) is leptokurtic, which implies that the distributions are peaked relative to normal distribution, while per capita income (PCI) and government size (GSIV) are platykurtic, meaning that the distribution of the variables are flat relative to normal distribution. Meanwhile, unemployment rate (UMP) and trade openness (TRDP) are mesokurtic, implying that the variables have normal distribution that is the distribution of the variables is bell shaped. Interestingly, the JarqueBera statistic for the null hypothesis of normal distribution for unemployment rate (UMP, government size (GSIZ) and per capita income (PCI) cannot be rejected at five percent level, while the null hypothesis of normal distribution for trade openness (TRDP) and economic growth (GRT) is rejected.

Table 1: Descriptive Analysis

\begin{tabular}{|l|c|c|c|c|c|}
\hline Variables & UMP & GRT & GSIZ & TRDP & PCI \\
\hline Mean & 12.473 & 3.244 & 2.103 & 7.844 & 0.244 \\
\hline Std. Dev. & 9.391 & 6.123 & 1.891 & 9.623 & 0.073 \\
\hline Skewness & 0.966 & -3.249 & 0.425 & 1.069 & 0.774 \\
\hline Kurtosis & 3.121 & 16.454 & 1.824 & 2.818 & 1.960 \\
\hline Jarque-Bera & 5.938 & 353.446 & 3.334 & 7.286 & 5.503 \\
\hline Probability & 0.051 & 0.000 & 0.189 & 0.026 & 0.063 \\
\hline Observations & 38 & 38 & 38 & 38 & 38 \\
\hline
\end{tabular}

Source: Authors' computation 2020.

The covariance estimate of the independent variables is presented on Table 2. It is observed from the Table that the independent variables have positive covariance estimate. This suggests that the independent variables have positive relationship with each other, that is, the pairs of independent variables move in the same direction.

Table 2: Covariance Matrix

\begin{tabular}{|l|l|l|l|l|}
\hline Variables & TRDP & GRT & GSIZ & PCI \\
\hline TRDP & 90.17347 & & & \\
\hline GRT & 18.37626 & 36.50908 & & \\
\hline
\end{tabular}




\begin{tabular}{|l|l|l|l|l|} 
GSIZ & 14.69008 & 3.369782 & 3.482631 & \\
\hline PCI & 0.392318 & 0.079506 & 0.117822 & 0.005258 \\
\hline
\end{tabular}

Source: Authors' computation 2020.

\subsection{Unit Root Test}

The Phillips-Perron (PP) test was adopted to investigate the unit root test. The results of the unit root test presented in Table 3 revealed that all the series were integrated of order one, which implied that the variables are I(1) variables except per capital income. The results revealed that per capital income $(\mathrm{PCl})$ is $\mathrm{I}(0)$ series. Consequently, the mix order of integration necessitates the use of Auto-regressive Distributed Lag Bound co-integration technique.

Table 3: Phillips-Perron (PP) Unit Root Test

\begin{tabular}{|l|c|c|c|}
\hline Variables & Level & After Differencing & Status \\
\hline UMP & 0.9265 & $-6.0645^{*}$ & $\mathrm{I}(1)$ \\
\hline GRT & $-4.8858^{\star *}$ & -7.6898 & $\mathrm{I}(0)$ \\
\hline GSIZ & -0.8017 & $-6.9639^{\star}$ & $\mathrm{I}(1)$ \\
\hline TRDP & -1.5384 & $-5.5219^{\star *}$ & $\mathrm{I}(1)$ \\
\hline PCI & -0.3002 & -2.9333 & $\mathrm{I}(1)$ \\
\hline
\end{tabular}

Source: Authors' computation 2020 . Note: ${ }^{*}$ and ${ }^{* *}$ denote $1 \%$ and $5 \%$ critical values respectively.

\subsection{Co-integration Estimate}

The bound co-integration result presented in Table 4 shows that the value of the F-statistics for the estimating model which is 4.6674 is greater than the upper bound critical value at $5 \%$, suggesting the presence of co-integration among the variables in the model, thus the study presents the long run ARDL Bound co-integration regression estimate.

Table 4: ARDL Bound Co-integration Test

\begin{tabular}{|l|c|c|}
\hline Estimated Model & \multicolumn{2}{|c|}{ F-Statistics } \\
\hline Critical Values & Lower Bound & Upper Bound \\
\hline $1 \%$ & 3.74 & 5.0674 \\
\hline $5 \%$ & 2.86 & 4.01 \\
\hline
\end{tabular}

Source: Authors' computation 2020.

\subsection{Regression Estimates on Trade Openness and Unemployment Rate in Nigeria}

The ARDL regression estimate presented in Table 5 shows that trade openness had significant and negative impact on unemployment rate in Nigeria over the years under review. This can be attributed to the fact that different trade policies over the years influenced unemployment rate, especially in terms of inflow and outflow of foreign commodities and services. Notably, the implementation of these policies may have influenced unemployment rate in Nigeria. This finding is consistent with those obtained by Keawphun (2016), Carrere, Grujovic and Robert-Nicoud (2015), and Felbermayr, Prat and Schmerer (2009) but in contrast to the findings by Jaewon (2011). Also, it is observed that per capita income, trade openness and government size have significant impact on unemployment in Nigeria, except economic growth rate. It is worthy to note that the current negative relationship between unemployment rate as dependent variable with trade openness and per capital income as independent variables follow the economic intuition. Meaning that, increases in volume of trade and per capita income bring about decline in the rate of unemployment in Nigeria. In addition, the coefficient of multiple determinations (R-squared) revealed that 96 per cent of variation in unemployment rate is jointly explained by the independent variables while the 
remaining 4 per cent of the variations in the unemployment rate is explained by variables not included in the model. This implies that the variables employed in the model are suitable for the analysis. Also, the result of the Durbin-Watson Stat of 1.99 revealed that the model is free from serial correlation.

In addition, the error correction mechanism results revealed the level of adjustment within the model. The negative and statistically (-0.3506) significance of the ECM term at $5 \%$ level, indicates a 35.06 per cent level of adjustment in terms of speed, which explain how the variables within the model adjusted over time i.e. from the short-run period to the long run period.

Table 5: ARDL Regression on Trade Policy and Unemployment Rate in Nigeria

\begin{tabular}{|l|c|c|c|c|}
\hline Variables & Coefficients & Std. Error & t-Statistics & Prob. \\
\hline C & 1.9796 & 2.1562 & 0.9181 & 0.3659 \\
\hline PCI & -119.252 & 43.7785 & -2.7239 & 0.0107 \\
\hline TRDP & -0.3637 & 0.0834 & -4.3612 & 0.0001 \\
\hline GSIZ & 3.8432 & 0.6708 & 5.7289 & 0.0000 \\
\hline GRT & -0.0876 & 0.0616 & -1.4221 & 0.1653 \\
\hline Coint-Eq(-1) & -0.3506 & 0.0936 & -3.7458 & 0.0008 \\
\hline R-squared: & 0.9614 & \multicolumn{5}{|l}{ AdjustedR-Squared: } & 0.9537 \\
\hline F-Statistics (Prob.) & $124.463(p<0.05)$ & \multicolumn{5}{l}{ Durbin-Watson Stat. } \\
\hline
\end{tabular}

Source: Authors' Computation, 2020.

\subsection{Diagnostics Tests}

The diagnostics tests for the regression estimate as shown by the normality, Breuch-Godfrey Serial Correlation LM and heteroskedasticity ARCH tests, suggest the appropriateness and robustness of the estimate. The results normality test showed that the Jarque-Bera probability value was greater than 0.05 suggesting that the residuals from the estimate were normally distributed. More so, the Breuch-Godfrey Serial Correlation LM and heteroskedasticity $\mathrm{ARCH}$ tests showed the absence of serial correlation in the estimates. The probability values from both estimates were insignificant at one percent critical level. The results of the diagnostics tests further strengthen the appropriateness of the ARDL regression estimates.

Figure 1: Normality Test

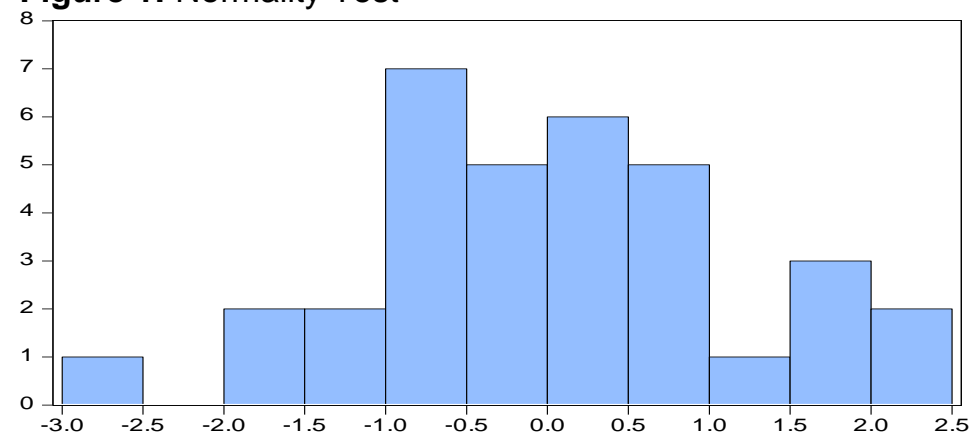

\begin{tabular}{lr} 
Series: Residuals \\
Sample 1984 2018 \\
Observations 34 \\
Mean & $-1.48 e-14$ \\
Median & -0.114908 \\
Maximum & 2.179932 \\
Minimum & -2.553397 \\
Std. Dev. & 1.135873 \\
Skewness & 0.111570 \\
Kurtosis & 2.587395 \\
& \\
Jarque-Bera & 0.311714 \\
Probability & 0.855681 \\
\hline
\end{tabular}

Source: Authors' Computation 2020. 
Table 6: Diagnostics Tests

\begin{tabular}{|c|c|c|c|}
\hline \multicolumn{4}{|c|}{ Breusch-Godfrey Serial Correlation LM Test } \\
\hline F-Statistics & 0.1391 & Prob. Value & 0.8713 \\
\hline Obs* R-squared & 0.6189 & Prob. Chi-Square. & 0.7338 \\
\hline \multicolumn{4}{|c|}{ Heteroskedasticity Test: ARCH } \\
\hline F-Statistics & 0.8506 & Prob. Value & 0.6248 \\
\hline Obs $^{\star} R$-squared & 15.1172 & Prob. Chi-Square. & 0.5161 \\
\hline Scaled explained SS & 2.9996 & Prob. Chi-Square. & 0.9998 \\
\hline
\end{tabular}

Source: Authors' Computation 2020.

\section{Conclusion and Policy Recommendation}

The objective of this study is to examine the relationship between trade openness and unemployment rate in Nigeria from 1980 to 2018. The study utilized the auto-regressive distributed lag (ARDL) technique and the result of the study showed that trade policy had negative and significant impact on unemployment rate in Nigeria. Thus, the outcome of this study rejected the null hypothesis that trade openness had insignificant impact on unemployment rate in Nigeria. The finding of this study is in line with Heckscher-Ohlin theory, Madanizadeh and Pilvar (2019), Martes (2018), Awad-Warrad (2018) and Kreickemeier (2006). The result of this study is in contrast with Famode, Makalamba and Ngbolua (2020), Mohler, Weder and Wyss (2018) and Jaewon (2011). The implication of this result is that trade policy provides employment opportunities, which has contributed to the reduction in unemployment rate in Nigeria. Thus, the study concludes that trade policy is a significant determinant of unemployment in Nigeria. Drawing from the conclusion, the study recommends that government should put in place trade policy that should enhance the provision of employment opportunities and this would contribute significantly to reducing unemployment rate in Nigeria. There is also the need for conscious economic policies that would increase government expenditure in the real sector which is expected to promote aggregate volume of investment in the country and contribute to employment generation.

\section{Reference}

Anjum, N. and Perviz, Z., 2016. Effect of Trade Openness on Unemployment in Case of Labour and Capital Abundant Countries. Bulletin of Business and Economic (BBE) Research Foundation for Humanity (FRH), 5 (1), pp. 44-58. http://rfh.org.pk/jur/wpcontent/uploads/2016/03/BBE-51-44-48.pdf

Arodoye, N. L. and lyoha, M. A., 2014. Foreign Trade-Economic Growth Nexus: Evidence from Nigeria. Central Bank of Nigeria (CBN) Journal of Applied Statistics, 5 (1), pp. 121-141. https://www.cbn.gov.ng/Out/2014/SD/Foreign\%20Trade-

Economic\%20Growth\%20Nexus Evidence\%20from\%20Nigeria.pdf

Awad-Warrad, T., 2018. Trade Openness, Economic Growth and Unemployment Reduction in Arab Region. International Journal of Economics and Financial Issues, 8 (1), pp. 179-183. https://www.econjournals.com/index.php/ijefi/article/download/5573/pdf

Carrere. C, Grujovic. A. and Robert-Nicoud. F., 2015. Trade and Frictional Unemployment in the Global Economy. CEPR Discussion Papers, No.10692. https://doi.org/10.1093/jeea/jvz074

Carrere. C., Fugazza. M., Olarreaga. M. and Robert-Nicoud, F., 2014. Trade in Unemployment. Working Papers, P101, FERDI. https://ferdi.fr/en/publications/trade-inunemployment 
Costinot. A., 2009. Jobs, Jobs, Jobs: A New Perspective on Protectionism. Journal of the European Economic Association, 7, pp. 1011-1041. https://doi.org/10.1162/JEEA.2009.7.5.1011

Dutt, P., Mitra, D. and Ranjan, P., 2008. International Trade and Unemployment: Theory and Cross-National Evidence. Economics Faculty Scholarship, No. 68. https://surface.syr.edu/ecn/68.

Ebrill, L., Stotsky, J. and Gropp, R., 1999. Revenue Implication of Trade Liberalization. IMF Occasional Paper No. 180, Washington D.C. https://www.imf.org/external/pubs/nft/op/180/ Famode, D. M., Makalamba, P. M., and Ngbolua, K. N., 2020. Econometric Assessment of Relationship between Trade Openness and Unemployment in Africa: The Case of Democratic Republic of Congo. International Journal of Economics and Business Administration, 6 (1), pp. 23-29. www. aiscience.org/journal/paperlnfo/ijeba?paperld=4809 Felbermayr. G, Prat. J. and Schmerer . H., 2011. Trade and Unemployment: What do the Data Say? European Economic Review, 55, pp. 741-758. https://doi.org/10.1016/i.euroecorev.2011.02.003

Gozgor, G., 2013. The Impact of Trade Openness on Unemployment Rate in G7 Countries. Journal of International Trade \& Economic Development, 23 (7), pp. 1018-1037. https://doi.org/10.1080/09638199.2013.827233

Halit, Y., 2013. Is Trade Liberalization a Solution to the Unemployment Problem? Portuguese Economic Journal, 12 (1), pp. 57-85. https://doi.org/10.1007/s10258-013-0088$\underline{9}$

Heckscher, E. F. and Ohlin, B., 1991. Heckscher-Ohlin Trade Theory, Translated, edited and introduce by Harry Flam and M. June Flanders, Cambridge, Mass., MIT Press.

Ifeakachukwu, N. P., 2018. Trade Liberalization and Trade Tax Revenue in Nigeria: Does

Causality Exist? International Journal of Management, Accounting and Economics, 5 (3),

pp. 181-189. http://www.ijmae.com/files/accepted/842 final.pdf

Jaewon. K., 2011. The Effects of Trade on Unemployment: Evidence from 20 OECD Countries. Research Papers in Economics from Stockholm University, Department of Economics, 19. http://www2.ne.su.se/paper/wp11 19.pdf

Keawphun, L., 2016. Impact of Trade Opening on Unemployment. Southern Illinois University Carbondale, Research Papers. https://opensiuc.lib.siu.edu/gs rp/680/

Kemal, A. R., Siddiqui, R., Siddiqui, R. and Kemal, M. A., 2003. An Assessment of the Trade Liberalization on Welfare in Pakistan: A General Equilibrium Analysis. Micro Impact of Macroeconomic Adjustment Policies (MIMAP) Technical Paper Series, 16, Pakistan Institute of Development Economics. http://www.pide.org.pk/Mimap/MIMAP16.pdf

Khattry, B. and Rao, J. M., 2002. Fiscal Faux Pas? An Analysis of the Revenue Implications of Trade Liberalization. World Development, 30, pp. 1431-1444. https://doi.org/10.1016.S0305-750X(02)00043-8

Kreickemeier, U., 2008. Unemployment in Models of International Trade. In: Greenaway D., Upward R., Wright P. (eds) Globalisation and Labour Market Adjustment. Palgrave Macmillan, London. https://doi.org/10.1057/9780230582385 5

Madanizadeh, S. A. and Pilvar, H., 2019. The Impact of Trade Openness on Labor Force Participation Rate. Applied Economics, 51 (24), pp. 2654-2668. https://doi.org/10.1080/00036846.2018.1558350

Martes, E., 2018. The effect of Trade Openness on Unemployment: Long-run Versus Shortrun. B.Sc. Thesis, Erasmus School of Economics, Erasmus Universiteit Rotterdam.

https://thesis.eur.nl/pub/43403/

McMillan, M. and Verduzco, I., 2011. New Evidence on Trade and Employment: An Overview. In: Jansen M, Peters, R and Salazar-Xirinachs JM eds. Trade and Employment, From Myths to Facts. ILO, Geneva, pp. 23-60. 
Mohler, L., Weder, R. and Wyss, S., 2018. International Trade and Unemployment: Towards an Investigation of the Swiss Case. Swiss Journal of Economics and Statistics, 154 (10). https://doi.org/10.1186/s41937-017-0006-7

Newfarmer. R. and Sztajerowska, M., 2012. Trade and Employment in a Fast-Changing World. Chapter 1, Policy Priorities for International Trade and Jobs, A Product of the International Collaborative Initiative on Trade and Employment, Coordinated by the OECD, pp. 1-70. https://www.oecd.org/site/tadicite/50286917.pdf

Nwaka, I. K., Uma, K. E. and Tuna, G. 2015. Trade Openness and Unemployment: Empirical Evidence for Nigeria. The Economic and Labour Relations Review, 26 (1), pp. 117-136. https://doi.org/10.1177/1035304615571225

Oloyede, B. B., 2014. Effect of Poverty Reduction Programmes on Economic Development Evidence from Nigeria. Arabian Journal of Business and Management Review (OMAN Chapter), 4 (1), pp. 26-37. https://doi.org/10.12816//0016565

Sodipe, O. A. and Ogunrinola, O. I., 2011. Employment and Economic Growth Nexus in Nigeria. International Journal of Business and Social Sciences, 2 (11), pp. 232-239. http://eprints.convenantuniversity.edu.ng/id/eprint/523

Ude, D. K. and Agodi, J. E., 2015. Does Trade Openness Make Sense? Investigation of Nigeria Trade Policy. International Journal of Academic Research in Economics and Management Sciences, 4 (1), pp. 6-21. https://doi.org/10.6007/IJAREMS/v4-i1/1469

United Nation Conference on Trade and Development (UNCTAD), 2013. The Impact of Trade on Employment and Poverty Reduction. TD/B/C/1/29.

https://unctad.org/en/PublicationsLibrary/tdr2014 en.pdf

Ventura, L., 2014. The Effect of Trade Openness on Female Unemployment Rate in Developing countries, M.Sc. Thesis, KDI School of Public Policy and Management.

https://archives.kdischool.ac.kr/bitstream/11125/30546/1/The\%20Effect\%20of\%20trade\%2 0openness\%20on\%20female\%20unemployment\%20rates\%20in\%20developing\%20countr ies.pdf

\section{Bio-note}

Nwosa Philip, Dr, is a PhD holder in economics and lecturer at the Department of Economics, Faculty of Social Sciences, Federal University Oye-Ekiti, Nigeria. Dr. Nwosa specialises in international economics and has been in active lecturing and research since 2011.

Keji Sunday, Mr, is a M.Sc. holder in economics and lecturer at the Department of Economics, Faculty of Social Sciences, Federal University Oye-Ekiti, Nigeria. Mr. Keji specialises in development economics and has been in active lecturing and research since 2013.

Adegboyo Femi, Mr, is a M.Sc. holder in economics and lecturer at the Department of Economics, Faculty of Social Sciences, Federal University Oye-Ekiti, Nigeria. Mr. Adegboyo specialises in monetary economics has been in active lecturing and research since 2019.

Fasina Oluwadamilola, Mr, is a M.Sc. holder in economics and lecturer at the Department of Economics, Faculty of Social Sciences, Federal University Oye-Ekiti, Nigeria. Mr. Fasina specialises in monetary economics and has been in active lecturing and research since 2016. 
Oradea Journal of Business and Economics, Volume V, Issue 2

Published on September 2020

\section{Appendix}

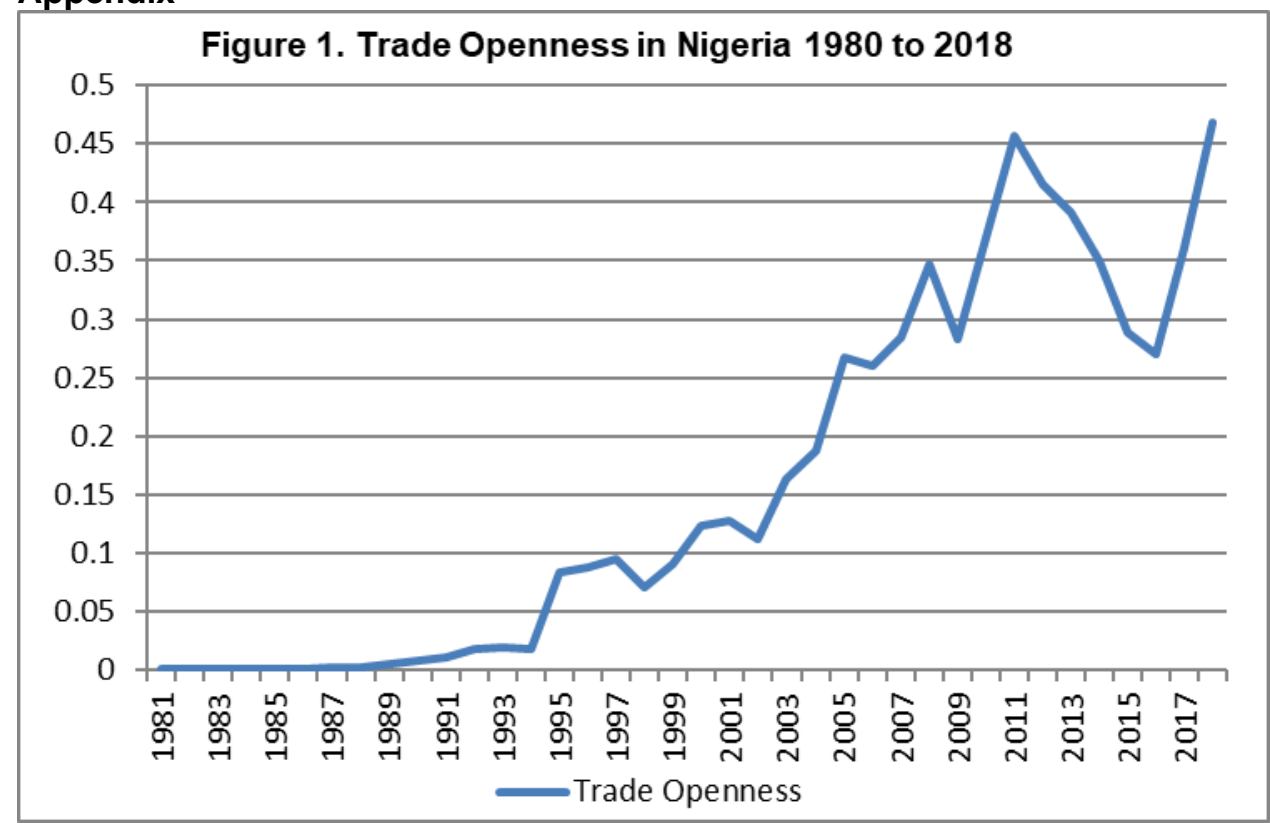

Source: Authors' Computation 2020.

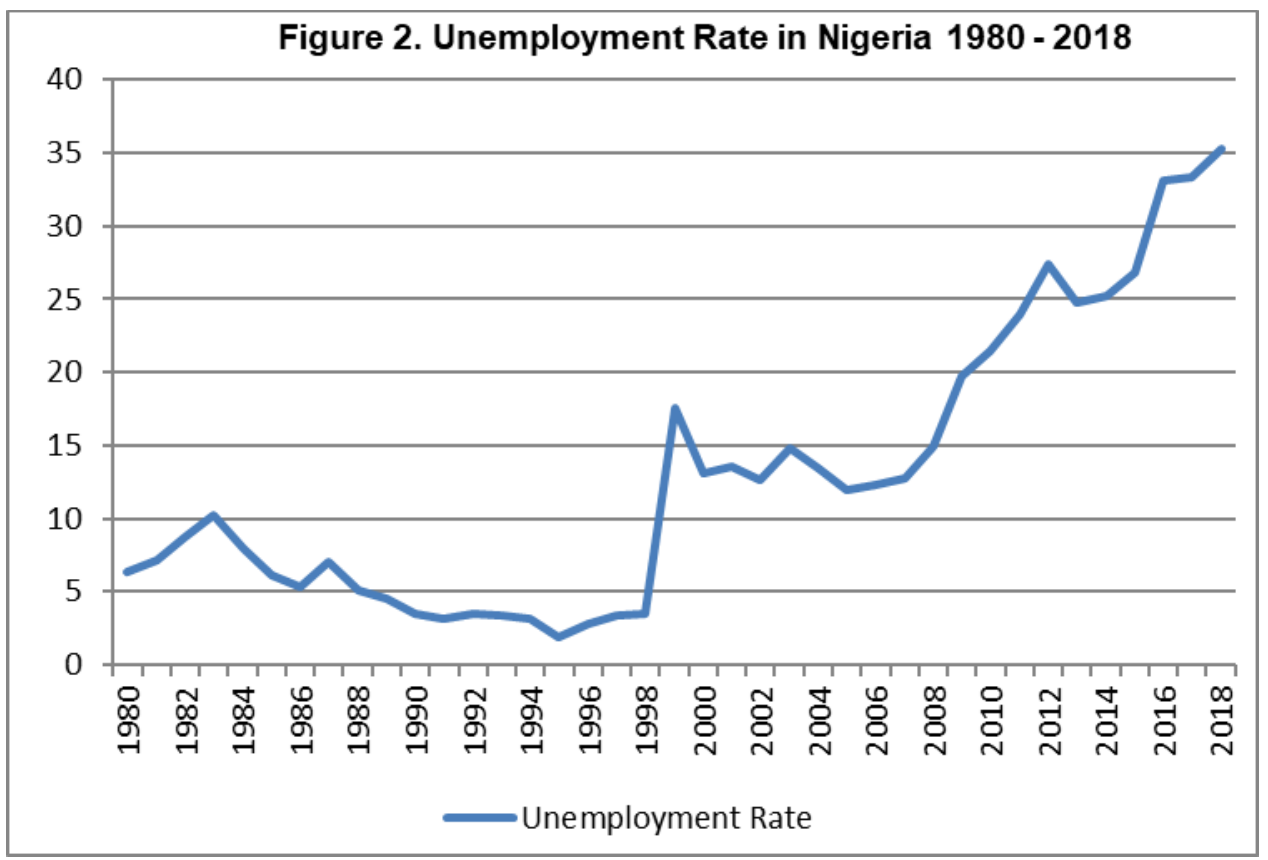

Source: Authors' Computation 2020. 